Uttaruk, Y., Laosuwan, T. (2020): Methods of estımatıon for above ground carbon stock in Nongbua-nonmee community forest, Maha Sarakham Province, Thalland. Agriculture and Forestry, 66 (3): 183-195

DOI: 10.17707/AgricultForest.66.3.15

Yannawut UTTARUK ${ }^{1}$, Teerawong LAOSUWAN ${ }^{2}$

\title{
METHODS OF ESTIMATION FOR ABOVE GROUND CARBON STOCK IN NONGBUA-NONMEE COMMUNITY FOREST, MAHA SARAKHAM PROVINCE, THAILAND
}

\section{SUMMARY}

The climate of the world today has changed greatly. This is mainly due to human activity causing large emissions of carbon dioxide $\left(\mathrm{CO}_{2}\right)$ from the reserve into the atmosphere, which is the main cause of global warming. This research methodology comprised of training for people in the community and local government sector, so they acquired knowledge and understanding of the causes and consequences of global warming. The people will also learn the adjustment toward weather atmosphere, the method in relieving global warming issues with the potential of the community forest as well as tree measurement techniques. The research method was based from the analysis of the carbon stock from the community forest from 3 different methods; which are 1) method of tree measurement by farmers in the community 2) Measurement, Reporting and Verification (MRV) online method, and 3) the application of Geoinformatics Technology (GIT). The research results found that 50 participants in the training session possessed over 80 percent of understanding toward causes and consequences from global warming, adjustment toward the change of weather atmosphere, and way to relieve the severity of global warming issue with a potential of community forest. Participants were also able to learn tree measurement techniques as well as able to record results. The results from the data analysis from the field survey, MRV online tool, and Geoinformatics Technology found that the community forest can complete the process of carbon stock that is equivalent to 5,256.66 $\mathrm{tCO}_{2} \mathrm{e}, 5,061.32 \mathrm{tCO}_{2} \mathrm{e}, 5,058.01 \mathrm{tCO}_{2} \mathrm{e}$ respectively.

Keywords: Community forest, Carbon stock, Ecological structure, Remote Sensing, Geoinformatics technology, MRV.

\footnotetext{
${ }^{1}$ Yannawut Uttaruk, (corresponding author: teerawong@msu.ac.th) Department of Biology, Faculty of Science, Mahasarakham University, Khamrieng, Katarawichai, Maha Sarakham, 44150, THAILAND.

${ }^{2}$ Teerawong Laosuwan, Department of Physics, Faculty of Science, Mahasarakham University, Khamrieng, Katarawichai, Maha Sarakham, 44150, THAILAND.

Notes: The authors declare that they have no conflicts of interest. Authorship Form signed online. 


\section{INTRODUCTION}

When radiations from the sun pierce through the atmosphere to the earth surface, it will enter the earth crust where the atmosphere will reflect some parts to space. The Greenhouse Gas (GHG) will act as an absorbent of the heat radiation, so the weather on the earth surface is warm and suitable for the existence of the living organisms. Thus, without these types of gases, the average temperature of the earth surface will decrease down to $0 \mathrm{~F}$ (approximately $17.78^{\circ} \mathrm{C}$ ). These GHGs in an appropriate amount will help average the heat on the earth surface to around $59^{\circ} \mathrm{F}$ (about $15^{\circ} \mathrm{C}$ ) (Gore, 2007). Thus, the high amount of Greenhouse Gases (GHG) that derived from human actions will increase the severity of the greenhouse effect, which results in the average temperature of the earth to increase drastically. This will lead to a tremendous change in the weather atmosphere. Significant GHGs are including Carbon dioxide $\left(\mathrm{CO}_{2}\right)$, Methane $\left(\mathrm{CH}_{4}\right)$, Nitrous oxide $\left(\mathrm{N}_{2} \mathrm{O}\right)$, Hydrofluorocarbons (HFC), Perfluorinated compounds (PFC), and Nitrogen trifluoride $\left(\mathrm{NF}_{3}\right)$ (Uttaruk and Laosuwan, 2016). The $\mathrm{CO}_{2}$ is a GHG that we give importance the most as it has up to 80 percent ratio of GHG that was released from human activities. Examples of human activities were fuel combustion from factories, deforestation to build resident or for agricultural purposes. The deforestation takes up almost 20 percent for the $\mathrm{CO}_{2}$ emission to the atmosphere (Uttaruk and Laosuwan, 2018). This was because trees and forests have excellent quality in the absorbent of $\mathrm{CO}_{2}$ (Senpaseuth et al., 2009). Therefore, the decreased number of forest area will result in an increasing amount of $\mathrm{CO}_{2}$ (Spracklen et al., 2015; Ounkerd et al., 2015; Bradford and Bell, 2017). At present; $\mathrm{CO}_{2}$ sequestration can be done in two methods which are 1) direct storage which is a method to prevent the diffusion of $\mathrm{CO}_{2}$ to the atmosphere, and 2) the indirect storage. This method is considered the best method for the carbon stock, which was to store it in trees and forests as trees and forests are the best sources for the carbon stock (IPCC, 2018).

Therefore, forest pays an essential role in the sequestration and emission of $\mathrm{CO}_{2}$. The sequestration or absorption of $\mathrm{CO}_{2}$ through the process of photosynthesis will be completed when tree brings about $\mathrm{CO}_{2}$ to use in absorbing foods, production, and creation of biomass (Cairns et al., 1997; Mekuria et al., 2015; Sisay et al., 2017). The forest had three significant effects on global warming; which are, 1) forest can absorb $\mathrm{CO}_{2}$ from the atmosphere and help to maintain and stabilize the earth's temperature. The second effect was the forest help release vapor into the atmosphere and increase moist. The third effect was that the forest covered the entire area of land from the sun, which also helps to reduce the heat in the earth surface (Laosuwan and Uttaruk, 2016a; Rotjanakusol and Laosuwan, 2018). Thus, international scientific research that was published in "National Science Foundation Report" from the United States stated that growing of trees, increase numbers of forest area, sustainable agriculture, and conservation of wetlands as well as a better management of soil all can help effectively reduce the severity of the global warming. Growing of forests will help reduce up to 37 percent of 11.3 billion tons of $\mathrm{CO}_{2}$ emission by 2030 or 
equal to the fuel combustion. This would be enough to maintain the earth surface not to exceed $2^{\circ} \mathrm{C}$ (The Nature Conservancy, 2019). For Thailand, in 1973 the area of the forest was about $221,707 \mathrm{~km}^{2}$ or approximately $43.21 \%$ of the area in Thailand. However, in 2017, the forestry area has tremendously reduced to about $163,981.28 \mathrm{~km}^{2}$ or equivalent to $31.68 \%$ (Royal Forest Department Thailand, 2019). The number of forest intrusion increased drastically every year. This was due to the significant change in the economic structures from agricultural to industrial; this resulted in the deterioration of forest and a drastic reduction in the number of forest (Royal Forest Department Thailand, 2016).

The management of the community forest is another trend that people in the community pay attention to more than ever before (Laosuwan et al., 2016b). The people also began hosting activities for the conservation and preservation of the forest (Poungngamchuen, 2013). Thus, each local area tends to have format and method on the management of the community forest differently, but less likely to succeed. This was because it was done only done through the participation of the people (Dyer et al., 2014; Samek et al., 2014). There was no cooperation from the government sector as much as needed. Therefore, the involvement from the people and the cooperation from government sectors as well as educational institutes are significant to the management of the community forest (Samek et al., 2011; Husseini et al., 2016; Tadesse et al., 2017). The objective of this research project was to development methods of estimation for above ground carbon stock in Nongbua-nonmee community forest, Bua Kho Subdistrict, Mueang District, Maha Sarakham province, Thailand. Thus to raise awareness within the community on the causes and consequences from the global warming, adjustment toward the changes of weather atmosphere, and method to relieve the severity of global warming issues with potential of the community forest.

\section{MATERIAL AND METHODS}

To make it concise and easy to understand, this research illustrated operational methods into steps as follow:

Transfer of Knowledge

The research transferred the knowledge through lecturer from the researcher on topics of 1) causes and consequences from global warming 2) the adjustment toward the change of the weather atmosphere and 3) method on relieving the severity of global warming from the community forest. Thus, the researcher has evaluated the results of participants in the training on the three topics above with questionnaires.

Operational Training

The researcher hosted an operational training on the carbon stock measurement techniques in biomass from trees within the study area through the placement of sample permanent plot in a size of $20 \times 20 \mathrm{~m}^{2}$ for the total of $15 \mathrm{plot}$ (Figure 1). Thus, participants acquired knowledge and understanding on 1) survey planning process 2 ) tree measurement techniques based on the theory as 
well as the use of Global Positioning System (GPS) to record results in the sample permanent plot and 3) method in recording surveyed data and store in a systematical manner.

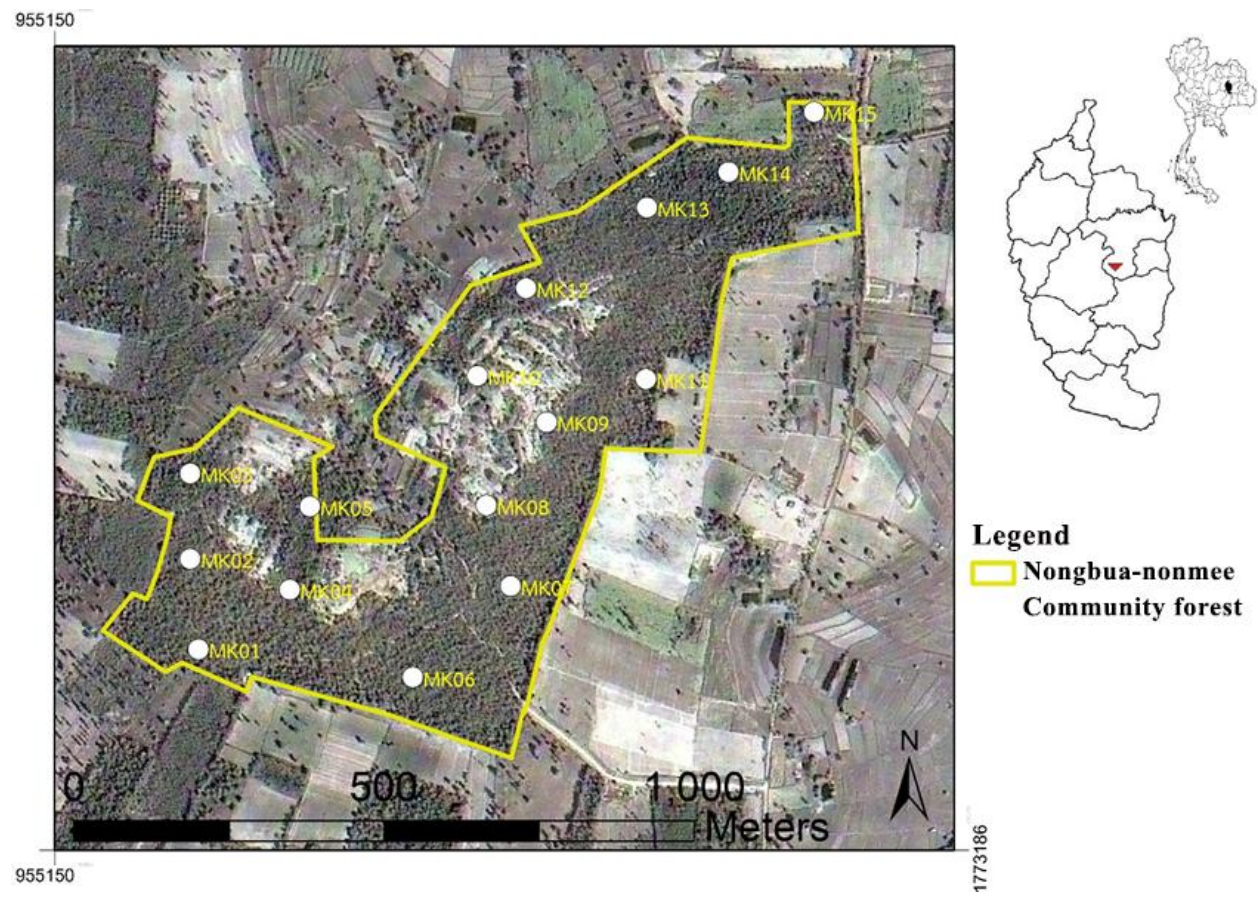

Figure 1. Nongbua-nonmee community forest

Data survey of ecological structures

This research has surveyed the ecological structures to evaluate the diversity of plant species in the community forest from the sample permanent plot in a size of $20 \times 20 \mathrm{~m}$ for the total of 15 plots. After that, the results were taken to analyze the plant communities through the evaluation of Importance Value Index (IVI) (Curtis and McIntosh, 1950; Mishra, 1968; Muller-Dombois and Ellenberg, 1974). The aim of this was to analyze the status and importance or dominant species that affect the amount of carbon stock within the forestry area.

Data analysis

There were three operational methods for the carbon stock analysis as follow: 1) The analysis of the carbon stock was from the tree measurements during the field survey by the people in the community. The researcher will use the results to calculate the amount of carbon stock in the community forest with the allometric equation for the mixed forest and deciduous forest as developed by Ogawa et al. (1965). The results will be displayed as seen in equation 1. 


$$
\begin{aligned}
& \mathrm{W}_{\mathrm{s}}=0.0396\left(\mathrm{D}^{2} \mathrm{H}\right)^{(0.9326)} \\
& \mathrm{W}_{\mathrm{b}}=0.003487\left(\mathrm{D}^{2} \mathrm{H}\right)^{(1.0270)} \\
& \mathrm{W}_{\mathrm{l}}=\left(0.28 /\left(\mathrm{W}_{\mathrm{s}}+\mathrm{W}_{\mathrm{b}}+0.025\right)^{-1}\right. \\
& \mathrm{ABG}=(\mathrm{Ws}+\mathrm{Wb}+\mathrm{Wl})
\end{aligned}
$$

Where;

$\mathrm{W}_{\mathrm{s}}$ is the weight of the stem $(\mathrm{kg}) ; \mathrm{W}_{\mathrm{b}}$ is the weight of branches $(\mathrm{kg}) ; \mathrm{W}_{1}$ is the weight of leaves $(\mathrm{kg}) ; \mathrm{D}$ is the diameter at breast height $(\mathrm{cm}) ; \mathrm{H}$ is the tree height (m)

2) The analysis on the carbon stock from MRV online tool. The MRV tool was developed by Michigan State University, USA (http://mrv.carbon2 markets.org/cas/login/) and can analyze the carbon stock with all types of trees.

3) The analysis of carbon stock with Geoinformatics Technology (GIT). The researcher used data from Landsat 8 satellite and analyzed as follow:

(1) Adjust the value of digital number to top of atmosphere reflectance (Uttaruk and Laosuwan, 2016),

(2) Analyze the vegetation with MSAVI-2 (Qi et al., 1994; Laosuwan and Uttaruk, 2014) with equation 2 ,

(3) The results based on the calculation from step2 will be analyzed for the Fractional Vegetation Cover (FVC) (Gitelson et al., 2002; Zhang et al., 2019) value with equation 3 , and

(4) The analyzed result from step 3 will be using to find the correlation with the amount of surveyed carbon from the field data.

$$
\text { MSAVI- } 2=\frac{2 * \mathrm{NIR}+1-\sqrt{(2 * \mathrm{NIR}+1)^{2}-8 *(\mathrm{NIR}-\mathrm{RED})}}{2}
$$

Where;

RED is the red band reflectance of Landsat 8; NIR is the Near Infrared band reflectance of Landsat 8

$$
\mathrm{FVC}=\frac{\left(\mathrm{VI}^{-} \mathrm{VI}_{\text {open }}\right)}{\left(\mathrm{VI}_{\text {canopy }}-\mathrm{VI}_{\text {open }}\right)} \times 100
$$

Where;

FVC is the tree canopy fractional cover; VI is the vegetation index; $\mathrm{VI}_{\text {open }}$ is the vegetation index of open areas;

$\mathrm{VI}_{\text {canopy }}$ is the vegetation index of tree canopy

\section{RESULTS AND DISCUSSION}

Results from the Transfer of Knowledge

There were 50 people in the area surrounding the community forest were interested in participation of the research project. From the evaluation of 
questionnaire, it found that participants acquired understandings of topic (1), (2), and (3) for 81 percent. About 8 percent understand certain topics and another 11 percent did not provide opinions in the questionnaire. Regarding the acknowledgment of changes toward the weather atmosphere - In general, the people will receive the news on the changes in weather atmosphere from a different form of media. However, the people still lack awareness on knowledge and consequences of the moves toward weather atmosphere. From the project, it was found that the group that was engaged in the transfer of knowledge tended to respond and become aware of the consequences than those who never receive knowledge transfer. This was because the people still lack the basic understanding on the carbon cycle in daily life.

Results from the Operational Training

The results for the evaluation of knowledge and ability for the tree measurement in 50 participants found that those that received operational training were able to measure the growth (diameter) and height of the tree. Participants were also able to record measured data into the record form. After the categorization, it was found that 37 percent of training participants were able to measure tree growth with tools. Additionally, 50 percent of participants were able to use estimation method; the rest of 13 percent did not provide any opinions. For the height measurement of tree, it was found that 24 percent of training participants used tools to measure, 68 percent used estimation, and the rest of 8 percent did not provide any opinions.

Results from the Data Survey of the Ecological Structures

The results from data survey of the ecological structure to estimate the diversification of species in the community forest found 33 different plant species from 23 families. Five plant species that were mostly found including:

1) Dipterocarpus tuberculatus Roxb. DIPTEROCARPA CEAE,

2) Shorea obtusa Wall. ex Blume: DIPTEROCARPACEAE,

3) Xylia xylocarpa (Roxb.) Taub. var. kerrii (Craib \& Hutch.) I.C. Nielsen : LEGUMINOSAE-MIMOSOIDEAE,

4) Dipterocarpus obtusifolius Teijsm ex Miq.: DIPTEROCARPACEAE,

5) Catunaregam tomentosa (Blume ex DC.) Tirveng.: RUBIACEAE.

After an analysis of the plant communities through the Importance Value Index (IVI) evaluation (Table 1) which consisted of Relative Density (RD), Relative Frequency (RF), and Relative Dominance (RDo), it was found that five dominant species were

1) Dipterocarpus tuberculatus Roxb.

2) Shorea obtusa Wall. ex Blume

3) Xylia xylocarpa (Roxb.) Taub. var. kerrii (Craib \& Hutch.) I.C. Nielsen

4) Dipterocarpus obtusifolius Teijsm ex Miq.

5) Catunaregam tomentosa (Blume ex DC.) Tirveng 
Table 1. Importance Value Index (IVI)

\begin{tabular}{|c|c|c|c|c|c|}
\hline No. & Scientific name & RD & $\mathbf{R F}$ & RDo & IVI \\
\hline 1 & Dipterocarpus tuberculatus Roxb. & 27.344 & 10.924 & 37.494 & 75.762 \\
\hline 2 & Shorea obtusa Wall. ex Blume & 19.271 & 9.244 & 10.796 & 39.311 \\
\hline 3 & $\begin{array}{l}\text { Xylia xylocarpa (Roxb.) Taub. var. kerrii (Craib } \\
\text { \& Hutch.) I.C. Nielsen }\end{array}$ & 10.417 & 9.244 & 7.668 & 27.329 \\
\hline 4 & Dipterocarpus obtusifolius Teijsm ex Miq. & 8.854 & 4.202 & 11.148 & 24.204 \\
\hline 5 & $\begin{array}{l}\text { Catunaregam tomentosa (Blume ex DC.) } \\
\text { Tirveng. }\end{array}$ & 4.688 & 8.403 & 3.673 & 16.764 \\
\hline 6 & Buchanania lanzan Spreng. & 2.344 & 5.882 & 2.630 & 10.856 \\
\hline 7 & Canarium subulatum Guillaumin & 2.604 & 4.202 & 2.657 & 9.463 \\
\hline 8 & Memecylon edule Roxb. & 2.344 & 3.361 & 3.631 & 9.336 \\
\hline 9 & Sindora siamensis Teijsm. \& Miq. & 2.083 & 4.202 & 2.635 & 8.920 \\
\hline 10 & Buchanania sp. & 2.344 & 2.521 & 2.185 & 7.050 \\
\hline 11 & Heterophragma sulfureum Kurz & 1.302 & 3.361 & 2.259 & 6.923 \\
\hline 12 & Lannea coromandelica (Houtt.) Merr. & 1.563 & 3.361 & 1.875 & 6.799 \\
\hline 13 & Terminalia alata Heyne ex Roth & 2.865 & 2.521 & 1.210 & 6.596 \\
\hline 14 & Gluta laccifera (Pierre) Ding Hou & 1.823 & 2.521 & 1.251 & 5.595 \\
\hline 15 & Strychnos nux-blanda A.W.Hill & 0.781 & 2.521 & 2.086 & 5.388 \\
\hline 16 & Pterocarpus macrocarpus Kurz & 1.302 & 2.521 & 0.949 & 4.773 \\
\hline 17 & Casearia grewiifolia Vent. var. grewiifolia & 1.042 & 2.521 & 0.539 & 4.102 \\
\hline 18 & Diospyros ehretioides Wall. ex G.Don & 1.042 & 2.521 & 0.459 & 4.021 \\
\hline 19 & Parinari anamense Hance & 1.042 & 1.681 & 0.947 & 3.670 \\
\hline 20 & Aporosa ficifolia Baill. & 0.521 & 1.681 & 1.422 & 3.623 \\
\hline 21 & Ellipanthus tomentosus Kurz var. tomentosus & 0.781 & 1.681 & 0.377 & 2.839 \\
\hline 22 & Litsea glutinosa (Lour.) C.B.Rob. & 0.521 & 1.681 & 0.344 & 2.545 \\
\hline 23 & Aporosa villosa (Wall. ex Lindl.) Baill. & 0.260 & 0.840 & 0.568 & 1.668 \\
\hline 24 & Diospyros ferra (Willd.) Bakh. var. ferra & 0.521 & 0.840 & 0.209 & 1.570 \\
\hline 25 & Millingtonia hortensis L.f. & 0.260 & 0.840 & 0.185 & 1.286 \\
\hline 26 & Ochna integerrima (Lour.) Merr. & 0.260 & 0.840 & 0.124 & 1.225 \\
\hline 27 & Grewia eriocarpa Juss. & 0.260 & 0.840 & 0.117 & 1.218 \\
\hline 28 & Cratoxylum cochinchinense (Lour.) Blume & 0.260 & 0.840 & 0.117 & 1.218 \\
\hline 29 & Mitragyna hirsuta Havil. & 0.260 & 0.840 & 0.098 & 1.199 \\
\hline 30 & Terminalia chebula Retz. var. chebula & 0.260 & 0.840 & 0.086 & 1.187 \\
\hline 31 & Lophopetalum wallichii Kurz & 0.260 & 0.840 & 0.086 & 1.187 \\
\hline 32 & Dillenia obovata (Blume) Hoogland & 0.260 & 0.840 & 0.086 & 1.187 \\
\hline \multirow[t]{2}{*}{33} & Peltophorum dasyrachis (Miq.) Kurz & 0.260 & 0.840 & 0.086 & 1.187 \\
\hline & Total & 100 & 100 & 100 & 300 \\
\hline
\end{tabular}


This also corresponded to plant types that were commonly found from the survey. In addition, the analysis of species diversity index was completed to identify the diversity of plant types by the Shannon-Wiener Index (Shannon and Weaver, 1949), it was found that in the 316 rai ( 1 hectare $=6.25$ rai) of community forest, there was 30 vegetation species in 33 families. The species diversity index was equivalent to 2.514 from the highest possible index of 3.497. It showed that the evenness of the dispersion index was equivalent to 0.719 as shown in Table 2 .

Table 2. The species diversity index

\begin{tabular}{|c|c|c|c|c|c|c|}
\hline $\begin{array}{c}\text { Community } \\
\text { forest }\end{array}$ & Area (rai) & $\begin{array}{c}\text { Number } \\
\text { type }\end{array}$ & $\begin{array}{c}\text { Number of } \\
\text { families }\end{array}$ & $\mathbf{H}^{\prime}$ & $\mathbf{H}_{\max }$ & $\mathbf{J}$ \\
\hline $\begin{array}{c}\text { Nongbua- } \\
\text { nonmee }\end{array}$ & 316 & 33 & 23 & 2.514 & 3.497 & 0.719 \\
\hline
\end{tabular}

Data analysis results:

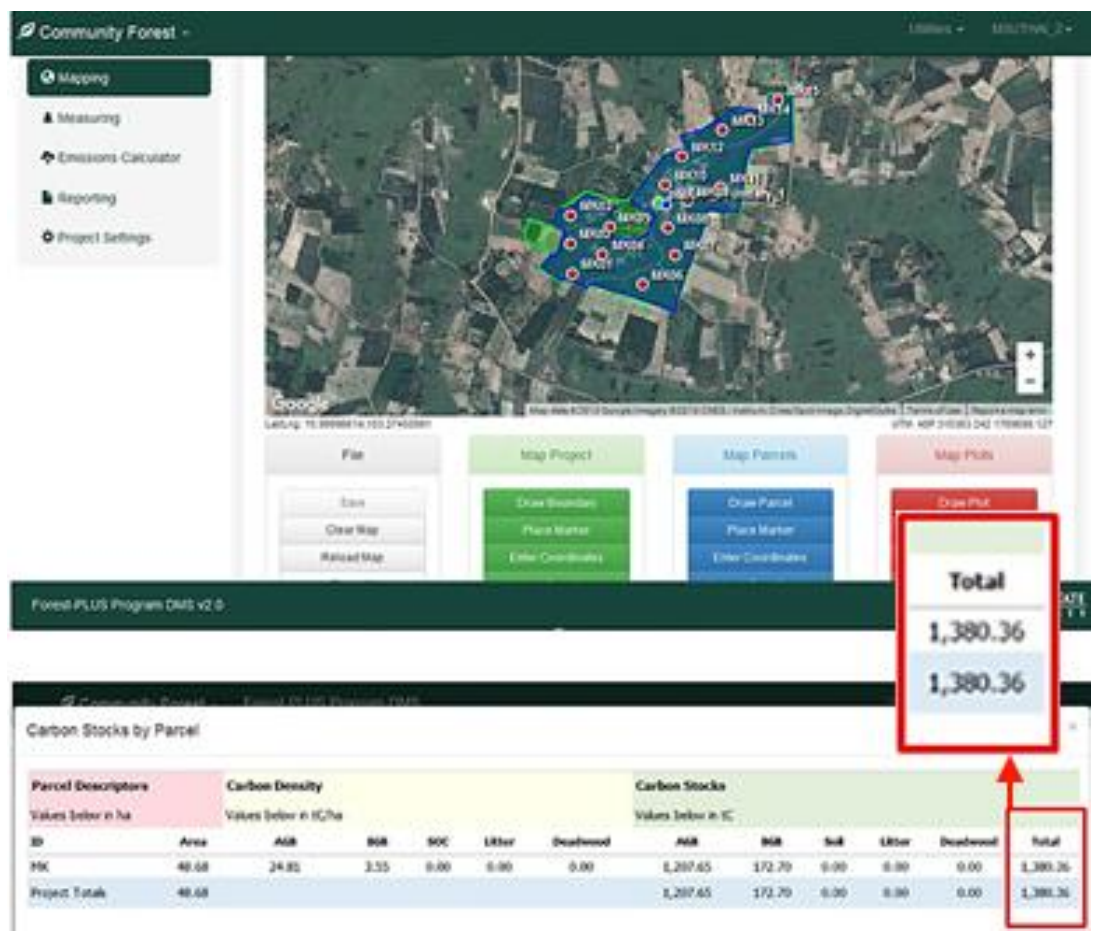

Figure 2. The carbon stock from MRV tool

1) The researcher has taken results from the tree measurements during the field survey of people in the community to calculate the amount of carbon stock in the community forest with allometric equation. The data analysis results found that 316 rai of community forest was able to complete the carbon stock that was equal to $1,433.64 \mathrm{tCO}_{2}$ or equivalent to5,256.66 $\mathrm{tCO}_{2} \mathrm{e}$. 
2) Login to the MRV system, it required

(1) Indicate qualities of the project based on the types and climate zone as well as contact detail for authorized person for the data management of the project.

(2) It required area scope for the study of the project, area of the educational institution, and location data on sample permanent lot used for the measurement in the field survey based on GPS to display the mapping data in the project.

(3) It required data analysis method, the analysis result of the carbon stock from MRV tool (Figure. 2) found that 316 rai of the community forest was able to held carbon stock that was equal to $1,380.36 \mathrm{tCO}_{2}$ or equivalent to $5,061.32$ $\mathrm{tCO}_{2} \mathrm{e}$.

3) The results from the data analysis with geoinformatics technology in this research project can be, as seen in Figure. 3.

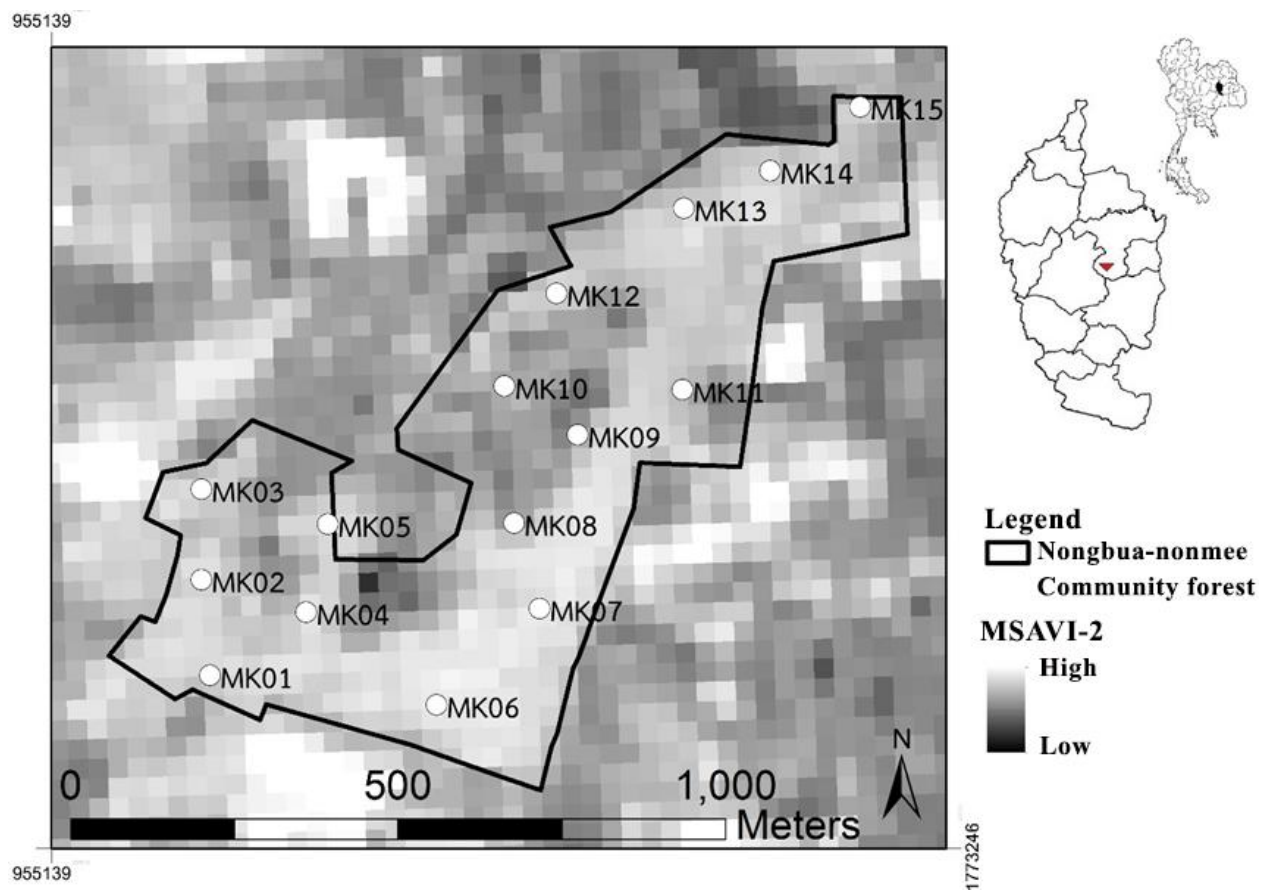

Figure 3. MSAVI-2 analysis

The FVC value was made to find the relation with the amount of carbon stock from the field survey, which results in the relation equation of $y=1.1952 \mathrm{e}^{0.0402 x}$ and the coefficient of determination of $r^{2}=0.890$. The equation was taken to calculate for the amount of carbon stock in 316 rai of the community forest, the amount of carbon stock was equal to $1,379.46 \mathrm{tCO}_{2}$ or equivalent to 5,058.01 $\mathrm{tCO}_{2} \mathrm{e}$. 
The results from the data analysis from the field survey, MRV online tool, and Geoinformatics Technology found that the Nongbua-nonmee community forest can complete the process of carbon stock that is equivalent to $5,256.66 \mathrm{tCO}_{2} \mathrm{e}$, $5,061.32 \mathrm{tCO}_{2} \mathrm{e}, 5,058.01 \mathrm{tCO}_{2} \mathrm{e}$ respectively. 955150

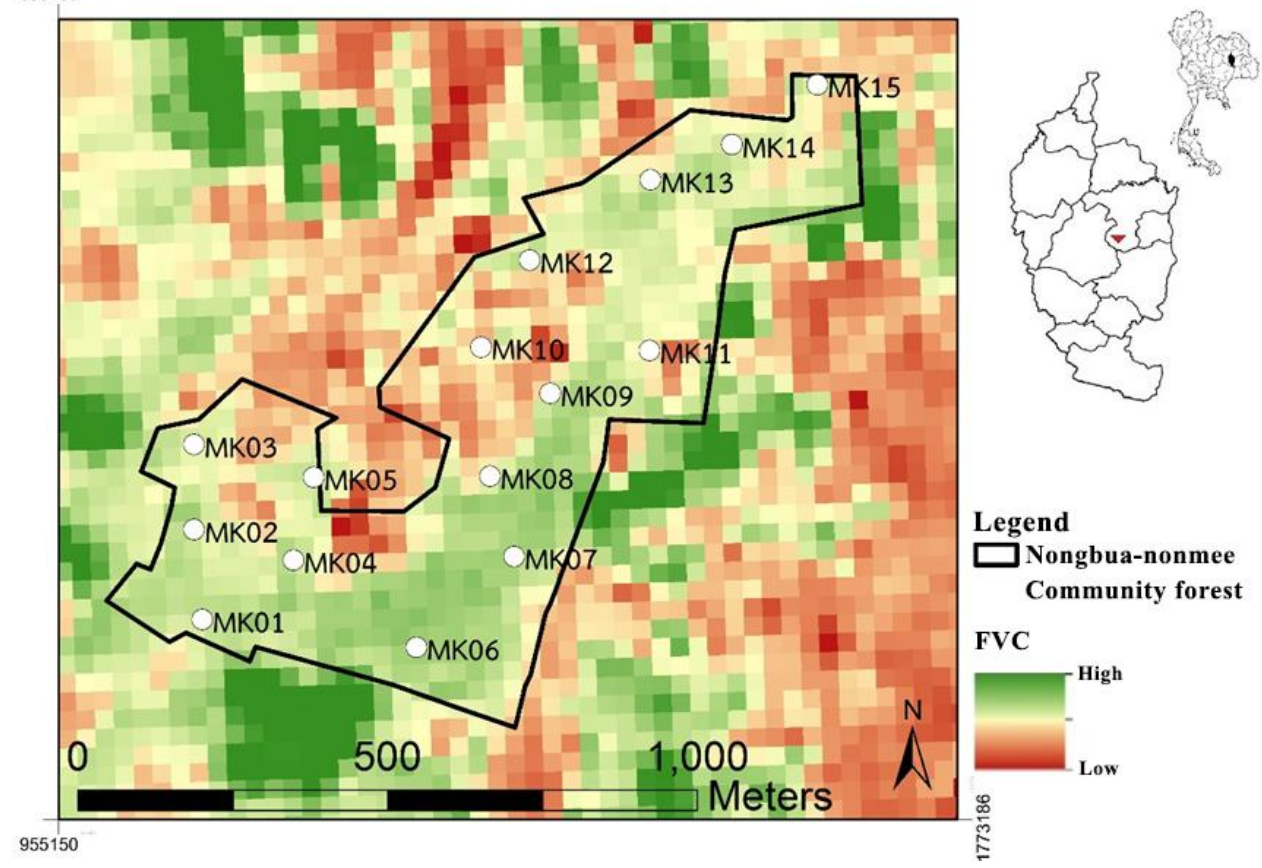

Figure 4. FVC analysis

In addition, the study also found that the result was in the same direction with other research such as: Estimation of carbon stock in south of western Carpathians from Moldova Noua forest district using G.I.S. data from managements plans (Chivulescu and Schiteanu, 2017), Improvement the evapotranspiration estimates using Remote Sensing Techniques and Fuzzy Regression (Parviz, 2018), and Community forest for global warming mitigation: the technique for estimation of biomass and above ground carbon storage using remote sensing method (Uttaruk and Laosuwan, 2018).

\section{CONCLUSIONS}

This research project was to propose methods of estimation for above ground carbon stock in Nongbua-nonmee community forest, Bua Kho Subdistrict, Mueang District, Maha Sarakham province, Thailand. Considering the study, the estimation of carbon stock requires no field study in all areas which will reduce the expense of field study and also reduce the time of researching while the data will be up-to-date and respond the demand of data in the abreast time. For this research project, it used advanced technology and applied to evaluate the carbon stock in the community forest that was convenient, quick, and 
reliable. The project used MRV online tool and Geoinformatics technology. Thus, the estimated result of the carbon stock was taken to test for the accuracy with Pair Sample T-test, it was found that all three methods have a statistically significant of $95 \%$. Each of the methods can be chosen to evaluate the carbon stock for the community forest.

\section{ACKNOWLEDGEMENTS}

This research was financially supported by National Research Council of Thailand (NRCT).

\section{REFERENCES}

Bradford, J.B., and Bell D.M. 2017. A window of opportunity for climate-change adaptation: easing tree mortality by reducing forest basal area. Frontiers in Ecology and the Environment, 15(1), 11-17.

Cairns, M.A., Winjum, J.K., Phillips, D.L., Kolchugina, T.P., and Vinson, T.S. 1997. Terrestrial carbon dynamics: Case studies in the former Soviet Union, the conterminous United States, Mexico and Brazil. Mitigation and Adaptation Strategies for Global Change, 1(4), 363-383.

Chivulescu S., Schiteanu I., (2017) Estimation of carbon stock in south of western Carpathians from Moldova Noua forest district using G.I.S. data from managements plans, Agriculture and Forestry, 63 (3): 39-46.

Curtis, J.T., and McIntosh, R. P. 1950.The interrelations of certain analytic and synthetic of phytosociological characters. Ecology, 31(3), 434-455.

Dyer, J., Stringer, L.C., Dougill, A.J., Leventon, J., Nshimbi, M., Chama, F., Kafwifwi, A., Muledi, J.I., Kaumbu, J.-M.K., Falcao, M., Muhorro, S., Munyemba, F., Kalaba, G.M., Syampungani. S. 2014. Assessing participatory practices in community-based natural resource management: Experiences in community engagement from southern Africa. Journal of Environmental Management, 137, 137-145.

Gitelson, A.A., Kaufman, Y.J., Stark, R., Rundquist, D. 2002. Novel algorithms for remote estimation of vegetation fraction. Remote Sensing of Environment, 80 (1), 76-87.

Gore, Al. 2007. An Inconvenient Truth: The Crisis of Global Warming. Penguin Books USA, New York, $192 \mathrm{p}$.

Husseini, R., Kendie, S.B., and Agbesinyale, P. 2016. Community participation in the management of forest reserves in the Northern Region of Ghana. International Journal of Sustainable Development \& World Ecology, 23(3), 245-256.

IPCC. 2018. Global warming of $1.5^{\circ} \mathrm{C}$. https://report.ipcc. ch/sr15/pdf/sr15_spm_ final.pdf (Accessed: 15 November 2019).

Laosuwan, T., Uttaruk, Y. 2014. Estimating Tree Biomass via Remote Sensing, MSAVI 2, and Fractional Cover Model. IETE Technical Review, 31(5), 362368.

Laosuwan, T., Uttaruk, Y. 2016a. Application of Geo-informatics and Vegetation Indices to Estimate Above-ground Carbon stock. Studia Universitatis Vasile Goldis Arad, Seria Stiintele Vietii, 26(4), 449-454. 
Laosuwan, T., Uttaruk, Y., Rotjanakusol, T., Laosuwan, N., Dumrongsukit, S., and Pattaaumpan., K. 2016b. Public Participation in the Management of Community Forests: A Case Study on Community Forests at Koke Kralong Pong Dang, Nong Reua, Na Chuak, Maha Sarakham. Hatyai Academic Journal, 14(2), 149-169.

Mekuria, W., Langan, S., Johnston, R., Belay, B., Amare, D., Gashaw, T., Desta, G., Noble, A., and Wale, A. 2015. Restoring aboveground carbon and biodiversity: a case study from the Nile basin, Ethiopia. Forest Science and Technology, 11(2), 86-96.

Mishra, R. 1968., Ecology Work Book. Oxford and IBH Publishing Co, Calcutta, 244 p.

Muller-Dombois, D., Ellenberg, H. 1974. Aims and Methods of Vegetation Ecology. John Wiley \& Sons. New York, $547 \mathrm{p}$.

Ogawa, H., Yoda, K., Ogino, K., and Kira, T. 1965. Comparative ecological study on three main types of forest vegetation in Thailand. II. Plant biomass. Nature and Life in Southeast Asia, 4, 49-80.

Ounkerd, K., Sunthornhao, P., and Puangchit, L. 2015. Valuation of Carbon Stock in Trees at Khao Wong Community Forest, Chaiyaphum Province. Thai Journal of Forestry, 34 (1), 29-38.

Parviz, L. (2018): Improvement the evapotranspiration estimates using Remote Sensing techniques and Fuzzy Regression. Agriculture and Forestry, 64 (2): 121-136.

Poungngamchuen, J., Supa-udomlerk Trirat, S., and Rungkawat, N. 2013. Participatory Development of the People in Community Forest Management Model: A Case Study of Baan Tha Pha Pao, Tha Pra Duk Sub-district, Maetha District, Lampun Province. KMUTT Research and Development Journal, 36(2), 215-234.

Qi, J., Chehbouni, A., Huete, A.R., Kerr, Y.H. 1994. Modified Soil Adjusted Vegetation Index (MSAVI). Remote Sensing of Environment, 48(2), 119-126.

Rotjanakusol T., Laosuwan T. 2018. Remote Sensing Based Drought Monitoring in The Middle-Part of Northeast Region of Thailand. Studia Universitatis Vasile Goldis Arad, Seria Stiintele Vietii, 28(1), 14-21.

Royal Forest Department Thailand. 2016. Forest Department Strategy 2016-2021. http://forestinfo.forest.go.th/Content/file/forest\%20strategy\%2059_64. pdf. (Accessed: 11 December 2016).

Royal Forest Department Thailand. 2019. Forest Information. http://forestinfo. forest.go.th/Content.aspx?id=72/ (Accessed: 02 October 2019).

Samek, J. H., Skole, D. L., Klinhom, U., Butthep. C., Navanugraha, C., Uttaruk, P., and Laosuwan, T. 2011. Inpang Carbon Bank in Northeast Thailand: A community effort in carbon trading from agroforestry projects. In Carbon stock Potential of Agroforestry Systems, 8, 263-280.

Samek, J. H., Skole, D. L., Klinhom, U., Laosuwan, T., Uttaruk, P., Butthep. C. 2014. Smallholders in Thailand and REDD+ and FLEGT linkages. ETFRN news 55: Linking FLEGT and REDD+ to Improve Forest Governance, 55, 134-144. 
Senpaseuth, P., Navanugraha, C., and Pattanakiat, S. 2009. The Estimation of Carbon Storage in Dry Evergreen and Dry Dipterocarp Forests in Sang Khom District, Nong Khai Province, Thailand. Environment and Natural Resources Journal, 7(2), 1-11.

Shannon, C. E., and Weaver, W. The Mathematical Theory of Communication. Urbana, IL, The University of Illinois Press, 1949,132 p.

Sisay, K., Thurnher, C., Belay, B., Lindner, G., Hasenauer, H. (2017). Volume and Carbon Estimates for the Forest Area of the Amhara Region in Northwestern Ethiopia. Forests, 8 (4), 122.

Spracklen, B.D., Kalamandeen, M., Galbraith, D., Gloor, E., and Spracklen, D.V. 2015. A Global Analysis of Deforestation in Moist Tropical Forest Protected Areas. PLoS ONE, 10(12), e0143886.

Tadesse, S., Woldetsadik, M., Senbeta, F. 2017. Forest users' level of participation in a participatory forest management program in southwestern Ethiopia. Forest Science and Technology, 13(4), 164-173.

The Nature Conservancy. 2019. Nature's Make or Break Potential for Climate Change.https://www.nature.org/en-us/what-we-do/our-insights/perspectivets/ natures-make-or-break-potential-for-climate-change/(Accessed: 15 Feb 2019).

Uttaruk, Y., and Laosuwan, T. 2016. Remote sensing based vegetation indices for estimating above ground carbon stock in orchards. Agriculture and Forestry, 62 (4), 193-201.

Uttaruk, Y., and Laosuwan, T. 2018. Community forest for global warming mitigation: the technique for estimation of biomass and above ground carbon storage using remote sensing method. Agriculture and Forestry, 64(3), 47-57.

Zhang, S., Chen, H., Fu, Y., Niu, H., Yang, Y., Zhang, B. 2019. Fractional Vegetation Cover Estimation of Different Vegetation Types in the Qaidam Basin", Sustainability, 11(3), 864. 